\section{THE FRAGMENTATION OF AFGHANISTAN}

$T$

he withdrawal of Soviet forces from Afghanistan has made clear that the crisis in that country was not only one of foreign intervention but also of the breakdown-indeed, fragmentation $\longrightarrow$ of a state. Having sacrificed over a million lives, the people of Afghanistan today face the unhappy alternatives of a government they reject and a resistance they fear. The turbulence of this once isolated land can no longer be a matter of indifference to a world whose powers have invested so much in the struggle. Five to six million Afghan refugees-more than a third of the country's population - strain the resources of neighboring Pakistan and Iran. The United States and U.S.S.R., having spent years of effort and billions of dollars and rubles, continue to pour in sophisticated firepower. A disaster for the Afghan people, a permanent danger for Pakistan, a serious irritant in U.S.-Soviet relations, the conflict in Afghanistan continues.

Is there a way out?

II

Afghanistan consists of the Hindu Kush mountain range with its fertile but isolated valleys, and the deserts, river valleys and steppes that flank it. The dispersed peoples of this sparsely settled area belong to a variety of ethnic groups, several of which are divided into rival tribes and clans. The dominant group is the Pashtuns, composed of the Durrani tribes from whom came the kings who ruled Afghanistan from 1747 to 1973 and their rivals, the Ghilzais and the eastern tribes, which spill over into Pakistan. There are also Persianspeaking Tajiks and Hazaras, Turkic-speaking Uzbeks and Turkmen and others.

These peoples became the inhabitants of a buffer state

Barnett R. Rubin is a Fellow of the U.S. Institute of Peace and was formerly Assistant Professor of Political Science at Yale University. He is also co-author, with Jeri Laber, of A Nation is Dying: Afghanistan under the Soviets, 1979-1987, Northwestern University Press, 1988. The views expressed in this article are those of the author alone, and do not necessarily reflect the views of the institute. demarcated by Britain and Russia in the early twentieth century. The state that developed within the boundaries drawn by these imperial powers never developed the capacity to extract sufficient resources from its own territory and population, but instead depended on the financial and military resources it obtained from foreign governments. A tribally based monarchy oversaw a weak administration imposed on a mosaic of peoples not integrated into a common economy or nationality. They retained their local systems of selfgovernment, often tribal institutions, which also provided the basis of popular military organization against foreign invaders or an overweening ruler.

This is not to say that the state had no legitimacy. It derived its legitimacy from traditional forms of representation and consultation, especially with the leadership of the Pashtun tribes; from the incorporation of Sunni Islam into the legal system; and from a history of jihad or holy war in resistance to foreign invaders. This legitimacy was conditional, however, on the state's observing strict limits against unwanted intervention in local or private affairs.

Under Prime Minister Mohammad Daoud a modern state funded by foreign aid developed in the 1950s, and a new elite emerged from the state education system. The state relied increasingly on this new class rather than on the tribal elites for performing governmental functions, yet it developed few mechanisms for this stratum to participate in politics. Important elite elements thus became alienated from the tribal monarchy and joined a variety of radical political organizations, from Communist to Islamist (fundamentalist).

The new intelligentsia were sharply divided as well as culturally separated by their education from the highly traditional rural masses. These divisions resulted partly from the Afghan government's policy of maintaining its precarious neutrality by balancing foreign powers against each other: for instance, the military officers were mostly Soviet-trained, engineers were American-trained, and judicial personnel were trained in Egypt's Al-Azhar Islamic University. The mix was explosive, and it eventually blew up.

A military coup in 1973 removed the king, Zaher Shah. His cousin, Daoud, the former prime minister who had resigned in 1963 , took power as the president of the Republic of Afghan- $P$ iram The pro-Soviet segment of the intelligentsia, including theofficers who had led the coup, had expected that Daoud's 


\section{FOREIGN AFFAIRS}

republic would allow them a share of power, but it soon became clear that Daoud had only used them in the service of his own goals.

Pro-Soviet military officers staged another coup in April 1978, killing Daoud. This time they turned power over to a revolutionary council of the People's Democratic Party of Afghanistan (PDPA), a Marxist-Leninist party. The Brezhnev regime, believing that the "correlation of forces" in the world was moving in favor of the U.S.S.R. and that "national democratic revolutions" led by "vanguard parties" were the wave of the future in the Third World, embraced the new Afghan leaders. These leaders' brutality and ill-considered radicalism, however, drove much of the population into its traditional pattern of revolt against overweening central government. They also defied Soviet advice to moderate their policies. The Soviet Union invaded in December 1979 and installed a more pliable Communist, Babrak Karmal, as leader.

The Soviets hoped to stabilize the PDPA regime but succeeded mainly in spreading revolt to previously unaffected regions. The United States, China, Pakistan, Saudi Arabia and others mounted an unprecedented effort to help the resistance. The growing violence of the Soviet counterinsurgency campaign ultimately claimed over a million lives and drove nearly one-third of the population into exile, mostly into Pakistan and Iran, where they provided recruits to the mujahedeen resistance. The Soviet occupation helped the PDPA maintain control of the cities, but it never quelled the rebellion.

Over eight years later, on April 14, 1988, Gorbachev's government agreed to withdraw its troops by February 15, 1989, tacitly admitting its failure to put down the revolt. The United States and Pakistan had previously agreed to cease aid to the resistance as the pullout began, but in the end the Reagan Administration decided against signing such an agreement. Secretary of State George Shultz first proposed a mutual cutoff of military aid by the United States and the U.S.S.R., in a formula known as negative symmetry. When the Soviets refused, the United States announced it would reserve the right to aid its friends in proportion to the aid given by the Soviets to theirs-positive symmetry. The Soviets reluctantly signed the agreement anyway and removed their troops. To the surprise of many, however, the Soviet withdrawal did not leave an isolated regime confronted with a united resistance
THE FRAGMENTATION OF AFGHANISTAN 153

that would sweep it away, but rather a fragmented society that neither accepted the regime nor proved able to overthrow it.

III

With the disintegration of the national framework of state administration in 1978 and 1979, Afghanistan's rural society reverted to traditional kinship or religious groups tied into a new national network of resistance parties.

The local fighting unit of the resistance is a band of men led by a commander. Some commanders who have come to control stable portions of population and territory have emerged as regional political leaders and preside over rudimentary local administrations. Many commanders started their jihad before linking up with the exiled political parties, but some had been involved in Islamic movements before the war and had contact with Afghan Islamists who had fled to Pakistan during Daoud's republic. These parties transmit foreign assistance and provide political representation in the international system.

The affiliation of commanders to parties is determined by a combination of patronage, traditional networks, reaction to local rivalries (a commander will join a different party from that of his traditional rival) and ideology. The commanders do not take orders from the exiled leaders. They derive their effectiveness and legitimacy not from party membership but from their ability to function as local leaders acting as intermediaries with outsiders.

Most of the commanders belonging to the country's Sunni Muslim majority are affiliated with one of the seven parties based in Peshawar, Pakistan, which also act as representatives of the over three million Afghan refugees in that country. Since May 1985 these parties have formed a loose alliance called the Islamic Union of Mujahedeen of Afghanistan.

The politics of the resistance have been shaped by both Islamic ideology and the ethnic composition of the leadership. Of the seven leaders of the Peshawar alliance, three are Ghilzai Pashtuns, one is an eastern Pashtun, one is a Tajik, and two are members of religious groups claiming Arab ancestry. In contrast to the elite of the old regime, none are Durranis. Furthermore, the alliance is dominated by fundamentalists, who played only a marginal role in national politics before the war.

The Hezb-e Islami led by Gulbuddin Hekmatyar, a Pashtun, is the most radical of the four fundamentalist parties in the 
alliance. It enjoyed the strong support of Pakistani President General Mohammad Zia ul-Haq and the Pakistani military intelligence apparatus, the Directorate of Inter-Services Intelligence (ISI). The Tajik-led party, the Jamiat-e Islami of Burhanuddin Rabbani, is the main channel for representation of the non-Pashtun minorities within the Sunni resistance. It of the non-Pashtun minoris other group. Another fundamentalist party is the Islamic Union for the Liberation of mentist pary is the It is essenAfghanistan, led by Abd-ur-Rabb-ur-Rasul Sayyaf. It is essentially a creation of Saudi Arabia, which has spent lavishly to establish a foothold for its Wahhabi sect of Islam in the Afghan resistance, even though Wahhabism has traditionally been anathema to Afghans. The three non-Islamist parties are led by traditional religious leaders and have mainly Pashtun tribal bases of support.

The largely Durrani political leaders who dominated Afghan politics during the royal and republican regimes, including the exiled former king, Zaher Shah, have no direct representation in the exiled leadership. Pakistan's rulers held representation in the exiled lo Afghan royal regime, which had pursued irredentist claims to Pashtun areas in Pakistan. and General Zia's government effectively prevented the exking or his representatives from playing any role in the resistance. Throughout most of the war the United States resistalice. Throughout most decisions about which Afghans to support.

About ten to 15 percent of Afghans are Shia Muslims. They are largely confined to the Hazara ethnic group, whose remote mountain area in central Afghanistan has hardly been affected by the main course of the war since 1981 . Its traditionalist shura (council) originally dominated the resistance there, but Tehran opposed it and created an alliance of eight radical Shia parties based in Iran. Only two or three have significant followings inside Afghanistan.

In an attempt to give the resistance a more state-like political structure, which would enable it to assume power following the expected collapse of the Kabul regime, the United States and Pakistan pressured the Sunni alliance into convening a shura to choose an interim government before the end of the Soviet troop withdrawal on February 15, 1989. But the shura, which convened in Rawalpindi, Pakistan, on February 10, failed to produce a broad-based government and exacerbated rather than resolved conflicts among the mujahedeen.
Iran campaigned vigorously for the maximum number of seats at the shura for the Shia, but Saudi Arabia weighed in with huge payoffs to assure that the clients of Iran, its main rival for influence in the Islamic world, received no representation. Zaher Shah's supporters were also refused representation. Seats supposedly reserved for "good Muslims" from Kabul remained empty. The entire shura was thus composed of delegates selected by the seven leaders of the Pakistan-based alliance. The isi controlled the security, and its officers openly attended all meetings. The final decisions about shura procedure took place in closed meetings held under ISI auspices. Major disputes were resolved in the office of General Hamid Gul, director of ISI. Saudi money determined much of the outcome of the vote that was finally taken, in particular the choice of the Saudi-backed Wahhabi leader Sayyaf as prime minister of the Afghan Interim Government (AIG) formed at the shura.

The shura and the events surrounding it intensified several conflicts within the resistance. The exclusion of the Iran-based alliance embittered the Shia in Afghanistan and further alienated Iran from the U.S.- and Saudi-supported Sunni mujahedeen. The choice of a Wahhabi as prime minister and the role of Saudi money, besides alienating the Shia and the Iranians, also intensified the bitter resentment many Sunni Afghans felt at what they perceived as Saudi attempts to buy their loyalty.

This resentment had been heightened by events elsewhere. In the Kunar region, Jamil ur-Rahman, a former commander of Hekmatyar's party, had established a Wahhabi organization outside the framework of the seven-party alliance. He was generously funded and armed by Saudi donors, and several hundred Arab volunteers fought alongside him. He and his followers, especially the Arabs, argued that governmentcontrolled areas of Afghanistan had become non-Muslim territory inhabited by apostates. When those areas were captured, they claimed, Islam required the application of the laws of futuhat, or conquest, which provided for the pillaging of property, execution of men and enslavement of women and children. In several areas of Kunar the Wahhabis and other mujahedeen under their influence had executed captured militia members. The hatred of the Arabs and Wahhabis among mujahedeen reached the point where armed clashes occurred.

The shura also intensified ethnic conflicts. Rabbani, the 
leader of the only party with a mainly non-Pashtun following, received the second smallest share of votes and consequently a relatively unimportant position in the interim government. He and his followers felt that Pakistan and the Pashtuns had conspired to squeeze them out of power.

The exclusion of Zaher Shah and his supporters alienated them from the interim government. Two days before the opening of the shura, on February 8, a group including many elders and dignitaries of the Durrani Pashtun tribes from Kandahar and western Afghanistan (the sector of the population from which the royal family descended) had staged a demonstration in Peshawar in favor of Zaher Shah. Club and gun-wielding militants of Hekmatyar's party broke up the demonstration while Pakistani police looked on.

Finally, the exiled political leaders hardly consulted the commanders. Few commanders attended the shura and some of those who did left early in disgust. Once constituted, the interim government did not engage in consultations with the commanders, nor did it offer to recognize local shuras as the base of a new representative and administrative structure for the Afghan state. In essence, the new ministers simply asked the commanders to fight in order to put them-the exiled leaders-in power in Kabul.

To gain both international recognition and credibility as a genuine contender for state power, the interim government had to establish itself on Afghan territory. This imperative led to the most crucial event since the Soviet withdrawal, the battle of Jalalabad.

IV

Jalalabad was an obvious target for the Peshawar alliance. Mujahedeen controlled the main highway from Pakistan up to the first ridge outside the city, and they had captured an excellent staging area in the Ghaziabad State Farm. The region's proximity to Peshawar and the ethnic composition of the area (mainly Ghilzai and eastern Pashtun) made it amenable to influence by the IS1 and the Peshawar alliance.

The mujahedeen had no general staff to plan such an operation, so the IS1 took it upon itself to fulfill this function, probably with the participation of some Americans. The timing of the attack was seemingly influenced by the upcoming meeting of the Organization of the Islamic Conference (oIc) the intergovernmental organization of Muslim states, which was to take place in Riyadh on March 13-16, 1989. The apparent goal was to have the AIG operating in Jalalabad in time to request recognition from the oIC and its member states.

The ISI, however, encountered resistance from at least some of the commanders in the area. These commanders argued that further political work was necessary in order to convince the garrison to defect. A direct assault, which they were not sure would succeed, would cause too many civilian casualties. Furthermore, they had little desire to install the government chosen at the shura. The ISI and AIG, however, prevailed over the commanders' doubts, and the assault began on March 7.

The mujahedeen overran the key government post at Samarkhel, on the last ridge before the city, and they advanced toward the airport, rendering it largely unusable for fixedwing aircraft. They also had some initial success in shutting off the road from Kabul, forcing the regime to resupply the garrison by helicopter.

But the hoped-for defections did not materialize, and the resistance began to falter. The regime's air power and artillery inflicted heavy losses on the mujahedeen. The government managed to reopen the road and bring through several large convoys. The mujahedeen rained down artillery on the city, but their relatively light shells, while killing civilians and destroying roads and houses, had little effect on the army's concrete bunkers. As a result, government morale in Kabul soared for the first time since the beginning of the Soviet withdrawal, and the Afghan president, Najibullah, made a hero of the governor of Ningrahar province, who had led the city's defense.

There were many factors, military and political, contributing to the failure of the mujahedeen at Jalalabad. The interpretation most favorable to the interim government emphasized that the Soviets had mounted an unprecedented (and unanticipated) massive supply effort, that the mujahedeen lacked mine-clearing equipment and the artillery for attacking concrete bunkers, and that they were still exposed to air power against which they were, if not defenseless, at least vulnerable. This analysis of what went wrong suggested the need for heavy artillery, mine sweepers and more Stinger missiles.

But equipment and technical training may not have been the key problems. After all, the offensive was partly predicated on the expectation of massive defections, yet it is no mystery why 
they did not occur. It was in the same sector that mujahedeen of one of the fundamentalist parties, led by Yunus Khales, had massacred 74 defectors from the garrison at Torkham in November 1988 and dumped their bodies in tea crates. In the nearby village of Shewa, Arab Wahhabi volunteers and others were reported (by mujahedeen) to have raped and sold women and to have taken videotapes as they cut the throats of captured militia members. Massacres of real or suspected government supporters had also occurred when mujahedeen overran several provincial centers after the Soviet withdrawal. During the battle for Jalalabad itself, Western reporters with the mujahedeen again saw fighters gun down government soldiers who were trying to surrender. ${ }^{1}$

The urban population from which most of the government forces are recruited is disturbed by the heavy hand of Pakistan and Saudi Arabia in the AIG and the resulting preponderance of Islamic radicals among the exiled leaders. They are also increasingly angered and frightened by the seemingly indiscriminate shelling of Kabul and other towns, which has caused many civilian casualties. Most of them adamantly reject the ideology of the PDPA, but they do want to continue the policies of gradual modernization that the fundamentalists oppose.

The marginal role to which Pakistan has confined the nationalist-modernist strand of Afghan politics in Peshawar has ironically strengthened the historically false claim of the PDPA to be the only defender of modernism in Afghanistan. For this reason, nostalgia for the former king has become stronger, even among social groups previously disaffected from the monarchy. The nostalgia is not for the institution but for Zaher Shah's moderate personality and the policies of his government. Most of the urban population would like to combine a more participatory political system, uniting aspects of Islam and Afghanistan's tribal heritage, with continued, voluntary liberalization of social norms. The interim government does not offer them any framework in which they can realize these goals, even if they would be glad to be rid of the PDPA.

Divisions among the mujahedeen, reflecting the AIG's lack of command and control, also crippled the offensive. An attack on a large objective such as a city requires coordination of attacks on enemy supply lines and on the main objective as well

${ }^{1}$ Newsweek, Mar. 27, 1989, p. 38 as, ideally, on diversionary targets. Yet attempts to keep the Jalalabad-Kabul road closed were hampered by the failure of rival parties to relieve each other in the rotation established by the ISI. The Persian-speaking Tajik mujahedeen north of Kabul abstained from the fighting out of resentment over the treatment of their party, Jamiat-e Islami, at the shura. Some of the mujahedeen opposed letting the Wahhabis and Arabs who had come down from Kunar approach Jalalabad, for fear of what they might do.

Attempts by the ISI to organize diversionary offensives elsewhere foundered on similar resentments and fears. The Durrani mujahedeen of Kandahar, like the Tajiks, refused to participate. According to resistance sources, the ISI "covered a table with money" and offered several truckloads of weapons to Kandahar commanders if they would attack the city, but the commanders, concerned for the welfare of their fellow tribesmen in the city and feeling excluded from the Pakistanisponsored exile leadership, refused. Instead, these tribally oriented traditionalist mujahedeen established a local shura that worked out a modus vivendi with the Kandahar garrison.

The interim government was further discredited in July, when violence between rival parties, a frequent occurrence, made the front pages of the world press and created open conflict in Peshawar for the first time. Sayyed Jamal, a commander of Hekmatyar's party, killed 30 mujahedeen of the Jamiat party in the Farkhar district of Takhar province. Five of the victims were killed in an ambush, but the remaining 25 were executed while in captivity. Those killed included severa senior commanders of the Supervisory Council of the North, the largest resistance political organization inside Afghanistan, which unites Jamiat-e Islami commanders from several provinces under the leadership of Panjsher Valley Commander Ahmad Shah Massoud. These mujahedeen were returning from a meeting at which Massoud had made plans for an offensive against remaining government strongholds in the region north and east of Kabul. Jamiat claimed that radio communications intercepted in Peshawar showed that, while the origin of the dispute may have been local, orders for the executions came from Hekmatyar's headquarters.

For the first time the other party leaders, led by Jamiat leader Rabbani and AIG President Mojaddedi, openly denounced Hekmatyar, calling him a "criminal" and a "terrorist." Rabbani demanded that those responsible be handed over 


\section{FOREIGN AFFAIRS}

to an Islamic court for trial. Hekmatyar, for his part, charged Massoud with collaborating with Kabul and killing his party's commanders, including Sayyed Jamal's brother. He demanded that Massoud be handed over to an Islamic court as well and announced that he was "suspending cooperation" with the interim government. Meanwhile, Massoud turned his considerable energy and resources to attacking Hekmatyar's strongholds in late August.

In September the AIG and its Pakistani sponsors made another attempt to establish the government on Afgh an territory by attacking the town of Khost near the Pakistani border, but even the attack on this smaller objective failed. Massoud announced an offensive against the government in the north in the second week of September, but it ended without taking a major target. An attack in the west against the air base at Shindand also fell short of its objective, and a convoy of over 1,000 trucks was able to reach Kandahar.

By mid-October, near the end of the fighting season, which is terminated by impassable mountain snowfalls in November, neither the AIG nor important commanders had won a major victory since the Soviet withdrawal. The interim government failed to establish itself in Afghan territory. Thus, the Kabul regime has been able to maintain control of the main territorial components of state power in Afghanistan, even though it cannot exercise sovereignty over most of the territory or population.

V

Since no political force has been able to establish a legitimate central power in the wake of the Soviet withdrawal, much of the countryside is under the de facto rule of local authorities or in a state of anarchy. Commanders continue to control most of rural Afghanistan. While some areas are torn by conflicts among rival fighters, in others the mujahedeen have established local shuras. These representative (although not democratic) bodies have the potential to serve as the basis of a new form of organization for the Afghan state. Najibullah has offered to recognize them as local authorities, permit them to keep their weapons (not that he has much choice in the matter), and provide them with aid, without even requiring them to recognize his authority formally. It is a testimony to the strength of the Islamic ideology and the hatred inspired by the PDPA's record of terror and subservience to the Soviet
THE FRAGMENTATION OF AFGHANISTAN

Union that so few have accepted his offers, even though they are more generous than anything the aIG has proposed to them.

Other portions of the countryside are controlled by government militias, a form of organization that emerged from the Soviet counterinsurgency strategy and developed further as part of the Afghan government's policy of national reconciliation. Many of these militias originated as mujahedeen fronts and subsequently changed their allegiances, although they generally have not joined the PDPA. They are exempted from government programs they find objectionable, often even conscription, and the government at least initially does not reestablish a state administrative apparatus in the area. Their basic responsibility is to keep their area clear of mujahedeen, and especially to keep open any major roads used by the government. The mujahedeen they oppose are often members of their traditional rival group. The militias' relations with Kabul are similar to the commanders' relations with the exiled parties. Their affiliation is based on patronage and opportunism, and they are subject to pressure and influence, but not hierarchical command and control.

The PDPA-led government has greater coherence than the resistance, but it too is strained. The party, founded in 1965, split into two antagonistic factions in 1967 and reunited under Soviet pressure a decade later. The two factions, Parcham and Khalq, have different social bases, and are in turn split into sub-factions loyal to different leaders and based in different parts of the state apparatus. Najibullah, who took over the party leadership in May 1986 at Soviet insistence, has succeeded in reducing factional conflict. Such conflict is muted, not gone, however, and it could resurface at any time. Most important is the conflict between the Khalqi-dominated army and the Parchami-dominated secret police.

The PDPA-dominated government maintains tight control over Kabul and a somewhat looser presence in most other major towns and regional centers. It has direct control over much of the flat steppe area adjacent to the Soviet border and can usually travel most of the main highways. Kabul has access to, although not direct control of, the areas controlled or patrolled by militias.

One-third of Afghanistan's population are international refugees. The vast majority live in Pakistan and Iran, where they are subject to a kind of dual control, shared by the host 
governments and the resistance parties recognized by the host governments. In Iran the parties seem to be much less involved in refugee administration. The Pakistani government, however, holds the parties responsible for the refugees. Each refugee family or individual must belong to a party that vouches for them before they can qualify for registration and assistance. The parties are also responsible for the security arrangements in the camps.

Thus, no political entity of Afghanistan enjoys anything close to a monopoly on control over the territory and population, the basic criterion for a state. The Soviet- and Americanled alliance systems are each supplying weapons, but the Kabul regime retains a substantial advantage since it is the only party with armored carriers, an air force and consistent access to a road network.

The result is what The Far Eastern Economic Review called "Back to Feudalism." As in the period prior to the shaky consolidation of the Afghan state a hundred years ago, military-political commanders hold regional bases of power to which the central state has little or no access. The state can negotiate with or fight against these centers, or play one off against the other, but it cannot govern them. The local rulers also exercise power precariously and are often subject to debilitating local conflicts, of which the battle between Hezb and Jamiat in July is only the most publicized. None of the political forces contending for state power has an adequate program for resolving tribal and ethnic competition, which has only increased since the Soviet withdrawal.

All major international and regional powers say that they support a political settlement providing for a nonaligned Afghanistan, the return of refugees and an end to the civil war. The combined effect of their policies, however, has been to perpetuate or aggravate the current situation.

The Soviet Union is continuing to mount an unprecedented supply effort. The U.S. government estimates that since the withdrawal there have been 25-40 flights a day, which had brought in nearly $\$ 2$ billion in military equipment by midOctober. The air bridge also ensures adequate food and fuel for key party and government personnel, who obtain their food through ration cards redeemable at restricted shops, similar to those in the U.S.S.R. The military supplies include weapons such as Scud-B missiles and MiG-21 jets. The United States claimed in October that Soviet "advisers" were working at Scud missile bases in Kabul. The Soviets have also continued their efforts to strike economic agreements directly with Afghan provinces and communities, especially in the north

The Soviets support a process of negotiation among Afghans aimed at setting up a "Government of National Reconciliation." They insist that the PDPA should be a part of such a process, a demand that all elements of the resistance reject. There is, however, a tentative compromise formula for the inclusion of "good Muslims" from Kabul, such as non-PDPA government officials. While the Soviets agree that the end of such a process might be the replacement of the current government, they have rejected the demand of the United States and Pakistan that Najibullah resign as a preliminary step. Gorbachev has reversed his earlier rejection of negative symmetry, or a mutual halt in assistance to both sides. He now advocates such a halt as part of a package including a ceasefire, an international conference on the neutralization and demilitarization of Afghanistan, and intra-Afghan negotiations over a new government.

The United States now opposes negative symmetry, ostensibly because the Soviets have created a new imbalance by supplying high-technology weapons and massive stockpiles since their withdrawal. Washington's lack of interest in exploring Soviet offers to negotiate these questions implies a different motivation, however. The original U.S. offer of negative symmetry was apparently based on an intelligence estimate, since proven wrong, that the Kabul regime would fall quickly. The United States now seems to want to encourage its clients into greater military successes, if not outright victory, before renewing negotiations.

The United States continues to support the interim government as the core of a new government for Afghanistan, and it insists that Najibullah must resign before the beginning of negotiations on a political settlement. The U.S. government seems to define an acceptable political solution as one in which the current government is replaced by a "broadened" AIG, despite the failure of the mujahedeen to create the military conditions for the success of such a demand.

The United States has continued to supply weapons for the mujahedeen. There are many claims about supposed halts or delays in the American arms supply. Congressional supporters 


\section{FOREIGN AFFAIRS}

of the mujahedeen attribute such delays to either managerial incompetence in the cia or a deliberate policy based on the mistaken estimate that the Kabul regime would collapse on its mistaken estinate the Soviet withdrawal. ${ }^{2}$ After August 1989 own soon after the Sovitedly accelerated, although the highweapons deliveries reporte is about $\$ 600$ million a year, far less est estimate of their value is about $\$ 600$ n

than Soviet supplies to the other side.

The United States told the resistance parties that cooperivation with the interim government was a condition for receiving aid. Hekmatyar's announcement that he was "he conflict participation" in that government as a result of the con with the Jamiat party revived the debate in Washington as to whether he should continue to receive arms (although he continues to receive aid at least from Saudi and other Arab sources). The United States decided to stop payments to the parties for running their separate offices and to attempt to parties for running their separfective commanders inside transfer weapo

The latter step faces great obstacles, as the parties control the existing logistic channels, and the actual transfer takes pereover, simply place supplying arms directly to the commande main ones together framework capable of will accentuate the existing

an alternative to the PDPA.

Since the withdrawal of Soviet troops, Pakistan has two main concerns. Some there would like to see the establishment of an Afghan Islamic Republic allied with both Iran and Pakistan, giving the latter "strategic depth" in its confrontation with India and acting as a bulwark against rather than a conduit of Soviet influence. This goal, popular in the Pakistani military, is . The AIG. To consistent with the American policy of promod the continued this end, the Pakistani military has supported the cont

resistance efforts to establish the Aakistanis is the creation of

The unanimous concern of Pakistanis is the creaton to conditions in Afghanistan that would allow the refugees to return. Advocates of the present policy in Pakistan argue that the refugees will go back only if there is an Islamic gov little in Afghanistan. Others say the present strategy has little

2 See for instance "Afghan Endgame: The CIA Has Bungled It," The Washington Post, Sept. (Hekmatyar] Says," The Washington 10, 1989; and "U.S.
THE FRAGMENTATION OF AFGHANISTAN

chance of succeeding and that the refugees will go back as long as they can enjoy reasonable physical security and noninterference from Kabul.

Under Prime Minister Benazir Bhutto, the Pakistani government has been divided and its position precarious. In constant danger of losing the support of either a parliamentary majority or the U.S. government, Bhutto has not dared to take any independent initiative. The military, still a potent force, has greatly benefited from the current policy. At a September 13 press briefing, however, Army Chief of Staff Mirza Aslam Beg gave indications that the military was rethinking its views on a political settlement, but he reiterated opposition to the participation of Zaher Shah.

Saudi Arabia and Iran are each committed to supporting the groups in Afghanistan that follow their respective (and antag. onistic) versions of Islam. This means that one of the major objectives for each is limiting the influence of the other. The Saudis succeeded in obtaining a strong position for their allies in the AIG, which means that they are allied with the current U.S.-Pakistani position. The Iranians, in reaction to the exclusion of their Shia client parties, have made accommodationist moves toward Najibullah and the Soviets, such as advocating a political solution based on negotiations between the mujahedeen and "non-Communists" in the Kabul regime, even without the prior resignation of Najibullah. Saudi Arabia and Iran have been united in opposing a role for Zaher Shah; to the Saudis he represents secularization, and to the Iranians he represents the principle of monarchy that their own revolution opposed.

VII

The central problem is whether there is a way to reestablish legitimate, though necessarily weak, national government in Afghanistan. None of the current contenders for power can do so alone.

The PDPA under Najibullah might be able to remain in power in Kabul and to reach open or implicit deals with commanders in different areas of the country, but it will not be able to claim their allegiance. While some order might gradually be established in this way, it would remain grudging and precarious. Many refugees would not risk returning, power would remain highly fragmented and reconstruction would be difficult. 
On the other hand, there now seems little chance for a military victory by mujahedeen forces over Kabul. The commanders show no sign of moving toward unity or coordination on a nationwide basis, and seizure of Kabul by either a major commander or the interim government, even if it were possible, would be more likely to precipitate a new round of civil war than to resolve the conflict.

A member of a prominent tribal family who served the royal regime as a diplomat and led his tribe in the jihad recently remarked: "Power in Afghanistan has broken into very small pieces; we must gather these pieces together." A traditionally fragmented society, Afghanistan also has traditional methods for overcoming fragmentation in time of crisis. Such a political process, based on a combination of tribal-ethnic, geographic and political representation, may be able partly to bypass the ideologues of Peshawar and Kabul and reconstitute a legitimate state.

The current situation, however, is more intractable than past episodes of revolt and disintegration in Afghanistan. The fact that both the state and the regional powers are now mobilized around antagonistic foreign-sponsored political ideologies, in addition to the traditional pole of conflicting ambitions, makes resolution especially difficult. Any one of four or five foreign governments could use its clients to torpedo an initiative it opposes.

Hence, restoration of stability in Afghanistan will require above all agreement by outside powers to disengage and promote stability. Withdrawal or destruction by the Soviet Union of sophisticated weapons and an agreement by the Soviet Union and the United States to cease shipments of weapons to their clients (negative symmetry) would be the most important components of such an agreement. The United States would also have to assure that Pakistan and Saudi Arabia would similarly refrain from arming their clients. War-weary Iran would probably go along if it were sure the Saudis would also keep out. Such an agreement, however, must be tied to a commitment by these powers to accept the outcome of an Afghan political process. The United Nations has been engaging in quiet consultations in an attempt to promote such an international consensus. U.N. officials also hint that the international actors could offer positive inducements to the Afghans, such as firm commitments to aid reconstruction tied to a political settlement.
THE FRAGMENTATION OF AFGHANISTAN

With such an agreement by external forces, Afghanistan's traditional processes of negotiation might have a chance to work. A key to the process is the involvement of the most prominent relatively neutral and prestigious Afghan political figure, Zaher Shah, who could attract support from refugees, most (though not all) mujahedeen, and the non-PDPA majority close adviser and relative of thes on the government side. A proposal for the composition of the former king has prepared a ering, known as the includes only 27 the Loya Jirga, or great council. His plan in a gathering of 27 representatives of the PDPA and Kabul regime probably accept rectly involved in crimes of for government figures not directly involved in crimes of the occupation, and the Soviets have also indicated interest in this plan

Who could organize a Loya Jirga? Aware that the institution of the monarchy no longer commands the loyalty of most of his compatriots, Zaher Shah has declined to convene a Jirga unilaterally. According to the proposal mentioned above, Zaher Shah could function as an elder member of a group of about 60 distinguished Af as ans with member of a group of iations, including rations, including legal experts. This expert group could and could provide therence of the Loya Jirga. The United Nations could provide the resources needed to carry out its mission. A related plan being developed in the U.N. secretary-general's office calls for the extension of the international consensus on Afghanistan mentioned above. This initiative would have the main foreign powers involved call on all opposition to Kabul-the parties in Peshawar and Tehran commanders, refugees, Western emigrés, the and Tehran, send delegates to a shura of about 100 people. The ex-king-to then choose a delegation of about 100 people. This shura would authority to pursue any of about ten, which would be granted including the calling of measures aimed at a political solution, Most of the calling of a Loya Jirga.

Most of the discussion about reconstituting legitimacy in Afghanistan has focused exclusively on the future national government. All significant political forces in Afghanistan now state that they favor national elections as a way of choosing the government, but it will be a long time before a state emerges that represents a broad enough consensus and has enough administrative capacity actually to carry out elections and assure that their results are respected. While some national 


\section{FOREIGN AFFAIRS}

elections have been held in Afghanistan, they have never determined the distribution of power. Despite the lack of other effective legitimation formulas, elections are not likely to settle national issues in Afghanistan any time soon.

Hence, two questions dealing with basic structures of the state that might persist through turmoil are important: the relation of the state to the segments of the society and the structure of the armed forces.

The emergence of parties and local administrations based on local and regional structures provides an opportunity to restructure the state on a more representative, perhaps federal, basis. The new state could incorporate the structures that have emerged from the resistance by providing for district and provincial shuras. These representative shuras should also be granted administrative powers over reconstruction and local economic development, as well as powers in fields such as primary education and others.

The structure of the armed forces could also reflect this more representative structure. Rather than a centralized force aimed at asserting the dominance of an exclusive center over the periphery, the army could mainly concentrate on preparing to mobilize the population for defensive jihad against future foreign invaders. Mujahedeen and militia could be incorporated into such a force, and the legacy of the resistance might be turned into nation-building rather than fragmentation.

If such a result is the best we can hope for, it is not the most likely we can expect. Whatever peace plan is tried, ten years of warfare have left a legacy that will be hard to overcome. The nearby example of Sri Lanka, which descended into the worst period of chaos and violence in its history after the signing of a peace accord, stands as a warning. But pouring more firepower into a fragmented society is not the way to rebuild it.

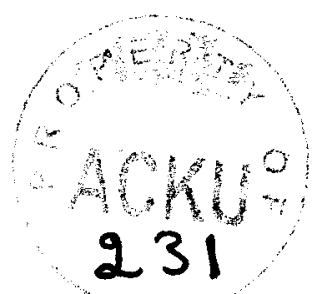

Pamela Constable

Arturo Valenzuela

CHILE'S RETURN TO DEMOCRACY

C

hile once boasted a longer history of stable democratic rule than most of its neighbors and much of Western Europe. Now it is the last major country on the South American continent to return to civilian government after a wave of authoritarianism. In December Chileans will have elected a new president after 16 years in the formidable grip of General Augusto Pinochet Ugarte. That election should set U.S. Chilean relations, plagued by a history of intervention and mistrust, on a more constructive, cooperative course.

Chile's transition to civilian rule has been remarkably smooth, despite several anxious moments. In a plebiscite on October 5, 1988, the people rejected Pinochet's bid to remain in power through 1997. The dictator conceded his defeat, opening the way for presidential and congressional elections, rather than clinging to power by force. Slowly the nation's tradition of democratic politics has reemerged, turning back the regime's attempt to uproot the system of partisan politics
forever.

What explains this success? The credit goes not so much to Pinochet, who had become as addicted to power as Noriega or Duvalier, and had every intention of remaining in office for a quarter-century. But his ambitions were thwarted by two elements. First, Chile's deeply rooted democratic and lawabiding political culture has survived 16 years of repression. During the transition, government opponents across the spectrum have proven themselves capable of uniting for a common purpose and have resisted radical behavior that might jeopardize the return to civilian control.

Second, the armed forces have remained highly disciplined,

Pamela Constable is an Alicia Patterson Foundation Fellow on leave from her position as Latin America Correspondent for The Boston Globe to study military rule in Chile. Arturo Valenzuela is Professor of Governnent, Director of the Latin American Studies Program at Georgetown University and author of several books on Chile. The authors are collaborating on a
book about the Pinochet years to be published by $199 \mathrm{l}$. 